\title{
Primary health care assessment tools: a literature review and metasynthesis
}

Lislaine Aparecida Fracolli ${ }^{1}$

Maria Fernanda Pereira Gomes ${ }^{1}$

Fabiana Rodrigues Zequini Nabão ${ }^{2}$

Mariana Souza Santos ${ }^{2}$

Verusca Kelly Cappellini ${ }^{2}$

Ana Cláudia Correa de Almeida ${ }^{2}$

${ }^{1}$ Escola de Enfermagem, Departamento de Saúde Coletiva, Universidade de São Paulo. Av. Dr. Enéas de Carvalho Aguiar 419, Cerqueira César. 05403000 São Paulo SP Brasil. lislaine@usp.br

${ }^{2}$ Faculdade de Enfermagem, Universidade Paulista.

\begin{abstract}
This study comprises a systematic review and metasynthesis of qualitative literature on national and international databases to identify the main tools used to assess Primary Health Care (PHC). A total of 3,048 results were returned for literature written in Portuguese, Spanish and English published between 1979 and 2013. Thirty-three articles/studies were selected after thorough reading and analysis. Eight of these studies addressed the use of one or more of the following validated PHC assessment tools: the WHO Primary Care Assessment Tool (PCET); the ADHD Questionnaire for Primary Care Providers (AQPCP); the General Practice Assessment Questionnaire (GPAQ), PACOTAPS (primary health care software); and the PCAT (Primary Care Assessment Tool). The study showed that the majority of these tools were used internationally. The PCAT and EUROPEP were used in Brazil and the most commonly used tool in this country was the PCAT. The results show that the use of research tools to assess PHC may assist in the creation of new proposals to improve family healthcare and that PCAT is the most adequate tool for this purpose. Key words Health assessment, Primary health care, Public health, Health services
\end{abstract}




\section{Introduction}

The worldwide debate about Primary Health Care (PHC) strategies has intensified over recent decades and measures to strengthen primary care are an integral part of the reorganisation of healthcare in various European and Latin American countries ${ }^{1}$.

The International Conference on Primary Health Care (the Alma - Ata Conference) held in 1978 marked a major milestone in the development of the concept of PHC by calling for "Health for all by 2000 " and a broader vision of healthcare that encompassed the sectoral dimensions of health and participation of the population'.

According to the Alma-Ata Declaration, PHC is the central function of national health systems and forms an integral part of a permanent process of sanitary assistance that includes prevention, promotion, cure and rehabilitation, and of the overall social and economic development of the community, involving cooperation with other sectors to promote social development and confront the social determinants of health ${ }^{2}$.

In Brazil, PHC is called basic health care and is characterised by a series of actions and sanitary practices in both the individual and collective spheres that encompass health promotion and protection, prevention of problems, diagnosis, treatment, rehabilitation and maintenance. The approach to basic health care is based on democratic and participative management and actions are focused on populations of well defined geographical region staking into account the specific characteristics of each area ${ }^{3}$.

Studies show that a given country's PHC framework depends on its approach to social health protection. In most European countries, outpatient services form an integral part of a universal health care system where the right to health is guaranteed at all levels through publically funded comprehensive universal systems in which PHC is seen as a gateway to the wider system.

However, in periphery countries, such as those in Latin America, PHC is selective and narrowly focussed on particular health problems. The expansion of health coverage depends on the private health insurance market that attends specific groups such as maternal and infant health. Health coverage in the majority of countries in Latin America is therefore segmented, with the coexistence of different schemes for different social groups. Primary care is incorporated only in the public sector through the implementation of selective programs, thus resulting in significant inequalities in access to health care ${ }^{1}$.

The context of the Brazilian health system is rather complex when it comes to approaches to primary care. Although the technically universal health system offers a diverse range of services and has expanded coverage to a large portion of the population previously without access, it coexists with private health schemes for the middle class thus creating a segmented and effectively dual system of healthcare which still remains insufficient. Although the population covered by the Unified Health System (SUS) is by no means small, the reach of services that should be guaranteed by the public system is questionable ${ }^{1}$.

The existence of different concepts of PHC shows that there are no set national or international standards, but rather a number of diverse models adapted to the social, economic and political context of a given country within a generalised tendency to embody a managed care approach under different politico-institutional contexts ${ }^{1}$.

According to Ibañez et al. ${ }^{4}$, research that focuses on organisational evaluations and care performance assessments of primary health care services and provides a critical insight into institutional mechanisms for monitoring and assessing primary health care is rare.

Given the nuanced understanding of the concept of PHC and the lack of research addressing primary care assessment, are view of literature on the current use of primary care assessment tools across health systems in different countries is considered of utmost importance.

Furthermore, the use of assessment tools to take a closer look at health systems allows a greater understanding of the following aspects of PHC in Brazil and other countries: perceptions of health service users, health professionals and managers; different health care frameworks; individual and collective care practices; and management practices.

The objective of this study is to therefore to carry out a review of literature on national and international databases to identify the tools currently used to assess Primary Health Care.

\section{Methodology}

A systematic search for qualitative research papers was undertaken followed by a metasynthesis of the literature. A systematic literature review is 
a research method which allows the researcher to group primary studies and extract the best scientific evidence ${ }^{5}$.

Since it synthesises all high quality research on a given question, the method provides the highest possible level of evidence for decision-making related to issues of therapy or treatment ${ }^{5}$. Furthermore, metasynthesis allows the researcher to interpret primary data and deepen his/her understanding of the phenomenon, thus facilitating the use of knowledge and research in decision making, to help set health policies and to define practices ${ }^{6}$.

The following research question was formulated using the PICO method which is used to select a specific intervention or phenomenon of interest: "What are the main validated data collection tools used to evaluate Primary Health Care?"

The identification and selection of articles/ studies was carried out in the following stages detailed in Figure $1^{7}$ :

1. Identification of the theme and formulation of research question;

2. Definition of data sources;

3. Establishment of study inclusion and exclusion criteria;

4. Data selection and processing;

5. Data analysis: evaluation of the quality of studies and interpretation of results.
This study used the following inclusion criteria: selected articles/studies must have used a validated data collection tool to evaluate PHC. The following exclusion criteria were also used: all articles/studies which did not use a validated data collection tool; articles/studies which addresses PHC but which evaluated quality of life of the population rather than the quality of PHC services; duplicated articles/studies; articles/studies that evaluated training and capacity building of PHC professionals.

The study considered articles/studies written in Portuguese, Spanish and English published between 1979 and 2013and indexed on the LILACS, CidSaúde, BDENF, IBECS, MEDCARIB, PAHO, MEDLINE databases and Cochrane and SciELO digital libraries as shown in Table 1.

The following keywords were used for the search of the LILACS (Latin American and Caribbean Health Sciences Literature) database: "Evaluation of Health", "Primary Health Care Evaluation", "Public Health", and "Health Service". After meticulous reading of the eight selected studies, six were excluded because they used unvalidated data collection tools.

The following key words were used for the search of the CidSaúde database (Literature about Healthy Cities/Municipalities): "Evaluation of Health", "Primary Health Care Evaluation", and "Health Service". The only article found was read

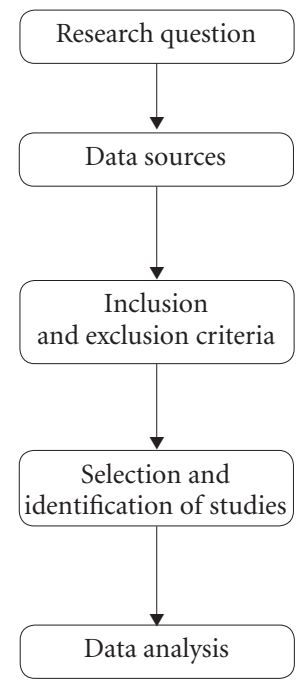

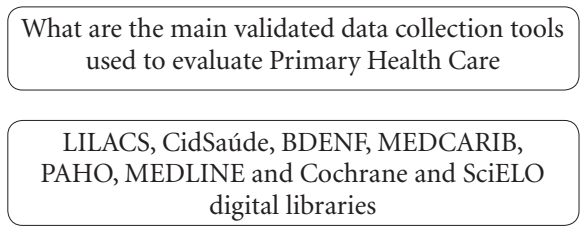

Inclusion criteria: selected articles/studies must have used a validated data collection tool to evaluate PHC.

Exclusion criteria: articles/studies that use an unvalidated data collection tool

Total number of studies found: 3048 . First
selection and identification: 33 studies that used a
validated data collection tool to evaluate PHC
Second and final selection after meticulous
reading of the full article: 8 studies selected
for metasynthesis

- 24 studies excluded because they evaluated quality of life among specific groups of people with different morbidities and training for PNC professionals.

- 1 duplicated study

Figure 1. Stages in the identification and selection of articles/studies for metasynthesis. 


\begin{tabular}{|c|c|c|c|c|c|}
\hline \multirow[t]{11}{*}{ 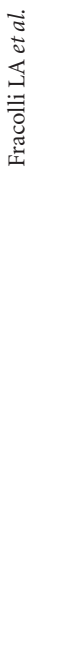 } & Table1. Studie & by data source ( 1 & to 2013$)$. & & \\
\hline & Data source & $\begin{array}{l}\text { Total number } \\
\text { of studies }\end{array}$ & $\begin{array}{l}\text { Studies using } \\
\text { assessment tools }\end{array}$ & $\begin{array}{l}\text { Studies selected for } \\
\text { metasynthesis }\end{array}$ & Search date \\
\hline & BDENF & 67 & 8 & 2 & 20 Sep 2013 \\
\hline & IBECS & 1 & 1 & 1 & 20 Sep 2013 \\
\hline & MEDCARIB & 2 & 0 & 0 & 20 Sep 2013 \\
\hline & PAHO & 4 & 0 & 0 & 14 Oct 2013 \\
\hline & MEDLINE & 40 & 1 & 0 & 06 Nov 2013 \\
\hline & BDENF & 90 & 0 & 0 & 01 Nov 2013 \\
\hline & IBECS & 2.761 & 22 & 4 & 01 Nov 2013 \\
\hline & MEDCARIB & 75 & 0 & 0 & 22 Sept 2013 \\
\hline & PAHO & 8 & 2 & 2 & 20 Sept 2013 \\
\hline
\end{tabular}

Source: produced by the authors (2014).

and it was found that the study used a validated data collection tool to evaluate PHC.

The following keywords were used for the search of the BDENF database (Nursing Data): "Evaluation of Health" and "Primary Health Care Evaluation". Two articles were found which were excluded after reading because neither used a validated data collection tool to evaluate PHC.

The following keywords were used for the search of the IBECS database (the Spanish Bibliographic Index of the Health Sciences): "Health Evaluation" and "Primary Health Care". The four studies found did not use a validated data collection tool to evaluate PHC.

The following keywords were used for the search of the MEDCARIB database: "Health Evaluation" and "Primary Health Care". Only one of the 40 results used a validated data collection tool to evaluate PHC. However, this study was not included in the metasynthesis because its direct focus was not PHC, but an evaluation of the severity of symptoms of diabetes within a PHC scenario.

The following key words were used for the search of the PAHO database: "Health Evaluation" and "Primary Health Care". After reading the summaries, none of the 90 studies found used a validated data collection tool to evaluate PHC.

The following MeSH terms were used for the search of the MEDLINE database (Medical Literature Analysis and Retrieval System Online): "health evaluation", "primary health care", "health services", "public health" and "questionnaires". Twenty-two of the 2,761 search results used a data collection tool to evaluate PHC. Meticulous reading of the 22 studies resulted in the selection of four articles/studies. Seventeen articles/studies were excluded because they did not deal directly with PHC, but rather evaluated quality of life among groups of people with different morbidities such as neoplasm, arterial hypertension and mental health disorders.

The term "evaluation" was used for the search of the Cochrane Library, resulting in 75 articles, which were all excluded because none dealt with PHC assessment tools.

The key words "Evaluation of Health", "Primary Health Care Evaluation", "Public Health" and "Health Service" were used for the search of SciELO (Scientific Electronic Library Online). After meticulous reading of the eight studies found by this search, two were found to use a validated data collection tool to evaluate PHC. However, these studies were duplicated because they had been found through the search of the LILACS database.

\section{Results}

The eight studies selected for the metasynthesis were published in national and international journals. Study participants were either PHC professionals or PHC service users and research used secondary data obtained from primary health centres.

The main methods used by the studies were interviews with the use of validated tools, as well as self-administered questionnaires as detailed in Chart 1.

\section{Discussion}

The search identified the use of five main assessment tools: the WHO Primary Care Assessment Tool (PCET); the ADHD Questionnaire for Pri- 
Chart 1. Main characteristics of the studies selected for metasynthesis (1979 to 2013).

\begin{tabular}{|c|c|c|c|c|c|c|}
\hline $\begin{array}{c}\text { Number and } \\
\text { reference } \\
\text { number }\end{array}$ & Method & Participants & $\begin{array}{l}\text { Data collection } \\
\text { tool used }\end{array}$ & Country & $\begin{array}{c}\text { Evaluation of Primary } \\
\text { Health Care }\end{array}$ & $\begin{array}{l}\text { Data } \\
\text { source }\end{array}$ \\
\hline $1^{(10)}$ & $\begin{array}{l}\text { Secondary data } \\
\text { provided by the } \\
\text { Brazilian Institute } \\
\text { for Geography } \\
\text { and Statistics } \\
\text { Foundation }\end{array}$ & $\begin{array}{l}45 \text { urban and } \\
\text { rural primary } \\
\text { health centres in } \\
\text { Pelotas (State of } \\
\text { Rio Grande do } \\
\text { Sul) }\end{array}$ & $\begin{array}{c}\text { PACOTAPS } \\
\text { (primary health } \\
\text { care software) }\end{array}$ & Brazil & $\begin{array}{l}\text { Using PACOTAPS to } \\
\text { systemise information } \\
\text { facilitates decision-making, } \\
\text { especially in primary } \\
\text { health centre management }\end{array}$ & SciELO \\
\hline $2^{(11)}$ & $\begin{array}{l}\text { Interviews with } \\
\text { physicians and } \\
\text { nurses from } \\
\text { primary health } \\
\text { centres in Porto } \\
\text { Alegre (State of } \\
\text { Rio Grande do Sul) } \\
\text { using the PCAT }\end{array}$ & $\begin{array}{l}\text { PHC professionals } \\
\text { in Porto Alegre } \\
\text { ( } 181 \text { working } \\
\text { in UBS centres, } \\
88 \text { working in } \\
\text { ESF centres, } \\
23 \text { working in } \\
\text { CSEM centres and } \\
77 \text { working in SSC } \\
\text { centres) }\end{array}$ & $\begin{array}{c}\text { PCAT } \\
\text { (Primary Care } \\
\text { Assessment } \\
\text { Tool) }\end{array}$ & Brazil & $\begin{array}{l}\text { Evaluation of the cardinal } \\
\text { and related domains of } \\
\text { PHC according to Starfield }\end{array}$ & LILACS \\
\hline $3^{(12)}$ & $\begin{array}{l}\text { Interviews of } \\
\text { patients in primary } \\
\text { health centres } \\
\text { located in the north } \\
\text { and centre-west of } \\
\text { the municipality of } \\
\text { São Paulo using the } \\
\text { PCAT }\end{array}$ & $\begin{array}{l}90 \text { Family Health } \\
\text { Programme } \\
\text { patients and } 90 \\
\text { without links to } \\
\text { the Family Health } \\
\text { Programme }\end{array}$ & $\begin{array}{c}\text { PCAT } \\
\text { (Primary Care } \\
\text { Assessment } \\
\text { Tool) }\end{array}$ & Brazil & $\begin{array}{l}\text { Evaluation of } \\
\text { comprehensiveness in } \\
\text { PHC in centres in the } \\
\text { municipality of São } \\
\text { Paulo based on "gateway" } \\
\text { criteria, links, range of } \\
\text { services, coordination, } \\
\text { family centeredness, and } \\
\text { community orientation }\end{array}$ & SciELO \\
\hline $4^{(13)}$ & $\begin{array}{l}\text { Interviews with } \\
\text { service usersand } \\
\text { health professionals } \\
\text { using the PCAT }\end{array}$ & $\begin{array}{l}100 \text { users with } \\
\text { tuberculosis } \\
\text { and } 14 \text { health } \\
\text { professionals } \\
\text { (physicians and } \\
\text { nurses }\end{array}$ & $\begin{array}{c}\text { PCAT } \\
\text { (Primary Care } \\
\text { Assessment } \\
\text { Tool) }\end{array}$ & Brazil & $\begin{array}{l}\text { Evaluation of the } \\
\text { integration of PHC } \\
\text { services in thecontrol of } \\
\text { TB, focussing on service } \\
\text { coordination }\end{array}$ & CidSaúde \\
\hline
\end{tabular}

mary Care Providers (AQ-PCP); the General Practice Assessment Questionnaire (GPAQ); PACOTAPS (primary health care software); and the PCAT (Primary Care Assessment Tool).

The WHO Primary Care Assessment tool (PCET) has been used in a number of countries that are undergoing deep and wide-ranging health reforms related to the social function and essential values that underpin healthcare provision. Reforms in primary health care are not always based on evidence, and progress may be driven by political arguments or the interests of specific professional groups.
However, health policy-makers today demand scientific evidence that health reforms are really making progress. The WHO therefore created the PCET with the aim of providing a structured approach to assessment based on specific aspects of the health system, such as governance, funding and resource generation, as well as factors that characterise good primary health care, including access, comprehensiveness, coordination and continuity ${ }^{8}$.

The PCET has three components: a national questionnaire regarding organisation and funding of primary health care; a questionnaire for 


\begin{tabular}{|c|c|c|c|c|c|c|}
\hline \multicolumn{7}{|c|}{ Chart 1 . continuation } \\
\hline $\begin{array}{l}\text { Number and } \\
\text { reference } \\
\text { number }\end{array}$ & Método & Participants & $\begin{array}{l}\text { Data collection } \\
\text { tool used }\end{array}$ & Country & $\begin{array}{c}\text { Evaluation of Primary } \\
\text { Health Care }\end{array}$ & $\begin{array}{c}\text { Data } \\
\text { source }\end{array}$ \\
\hline $5^{(8)}$ & $\begin{array}{l}\text { Use of an } \\
\text { assessment tool with } \\
\text { three components: } \\
\text { a national } \\
\text { questionnaire } \\
\text { regarding } \\
\text { organisation and } \\
\text { funding of primary } \\
\text { health care, a } \\
\text { questionnaire for } \\
\text { family doctors, and } \\
\text { questionnaire for } \\
\text { family health centre } \\
\text { patients }\end{array}$ & $\begin{array}{l}\text { 1,548 family health } \\
\text { centre users ( } 738 \\
\text { in Bolu and } 810 \\
\text { in Eskisehir), } 78 \\
\text { family doctors ( } 37 \\
\text { in Bolu and } 41 \text { in } \\
\text { Eskisehir) }\end{array}$ & $\begin{array}{c}\text { WHO } \\
\text { Primary Care } \\
\text { Assessment } \\
\text { tool (PCET) }\end{array}$ & Turkey & $\begin{array}{l}\text { Evaluation of primary } \\
\text { health care in the cities } \\
\text { of Bolu and Eskiseirin } \\
\text { Turkey }\end{array}$ & LILACS \\
\hline $6^{(9)}$ & $\begin{array}{l}\text { Focus groups of } \\
\text { PHC professionals } \\
\text { and use of AQ-PCP }\end{array}$ & $\begin{array}{l}181 \text { PHC } \\
\text { professionals (134 } \\
\text { in rural areas and } \\
46 \text { in urban areas) }\end{array}$ & $\begin{array}{c}\text { ADHD } \\
\text { Questionnaire } \\
\text { for Primary } \\
\text { Care Providers } \\
\text { (AQ-PCP) }\end{array}$ & $\begin{array}{l}\text { United } \\
\text { States }\end{array}$ & $\begin{array}{l}\text { Evaluation of the } \\
\text { perceptions of PHC } \\
\text { professionals with } \\
\text { respect to their role and } \\
\text { management challenges, } \\
\text { and differences between } \\
\text { professionals working } \\
\text { in rural areas and those } \\
\text { working in urban areas }\end{array}$ & Medline \\
\hline $7^{(14)}$ & $\begin{array}{l}\text { Use of the self- } \\
\text { administered GPAQ }\end{array}$ & $\begin{array}{l}\text { 2,600 patients } \\
\text { of the Family } \\
\text { Medicine Clinic }\end{array}$ & $\begin{array}{c}\text { General } \\
\text { Practice } \\
\text { Assessment } \\
\text { Questionnaire } \\
\text { (GPAQ) }\end{array}$ & Thailand & $\begin{array}{l}\text { Evaluation of } \\
\text { PHCincluding care access, } \\
\text { continuity of care, doctor } \\
\text { communicationand } \\
\text { medical knowledge, and } \\
\text { general level of satisfaction }\end{array}$ & Medline \\
\hline $8^{(16)}$ & $\begin{array}{l}\text { Interviews with } \\
\text { parents and } \\
\text { guardians of } \\
\text { children under } \\
\text { two years }\end{array}$ & $\begin{array}{l}468 \text { parents and } \\
\text { guardians of } \\
\text { children registered } \\
\text { in } 18 \text { primary } \\
\text { health centres in } \\
\text { Porto Alegre }\end{array}$ & $\begin{array}{c}\text { PCAT } \\
\text { (Primary Care } \\
\text { Assessment } \\
\text { Tool) }\end{array}$ & Brazil & $\begin{array}{l}\text { Validation of the PCAT-CE } \\
\text { to evaluate child PHC }\end{array}$ & Medline \\
\hline
\end{tabular}

Source: produced by the authors (2014).

family doctors; and a questionnaire for service users ${ }^{8}$.

The ADHD Questionnaire for Primary Care Providers (AQ-PCP) was developed to evaluate the perceptions of primary care providers regarding their role, the challenges associated with diagnosis of attention deficit hyperactivity disorder (ADHD), and clinical activities specific to the care of children with ADHD. The items of this questionnaire were developed based on the following criteria: a careful revision of the recommendations for performing an evaluation of the disorder contained in the American Academy of Paediatrics Guidelines for treatment of ADHD; a revision of the role of primary health care providers; and focus groups of primary health care providers?. 
PACOTAPS is a primary health care software developed using the programming language $\mathrm{Vi}$ sual Basic 5.0. The secondary data and outpatient care demand modules of this program were tested in a primary health centre in Pelotas in the State of Rio Grande do Sul. The tool proposes an interface between two fields of knowledge: epidemiology and information technology. By processing the information contained on patient forms, PACOTAPS provides secondary data on the age and sex distribution of a specific population, outpatient care demand, and all patient attendances at a given primary health centre ${ }^{10}$.

The General Practice Assessment Questionnaire (GPAQ) was developed by the National Primary Care Research and Development Centre at the University of Manchester for the 2003 GP contract. The GPAQ helps practices find out what patients think about the care provided by doctors and focuses on specific features of general practice, such as access, the interpersonal aspects of care, and continuity of care ${ }^{14}$.

This study observed that the PCAT (Primary Care Assessment Tool) and European Task Force on Patient Evaluation of General Practice Care (EUROPEP) are tools currently used in Brazil. The most commonly used tool in Brazil is the PCAT, since it is widely accepted and validated in the United States, Spain and other countries.

O PCAT was developed by Starfield et al..$^{15}$ at the Johns Hopkins Populations Care Policy Center for the Underserved Populations in Baltimore, Maryland based on a theoretical framework of primary care domains and characteristics. It measures the presence and extent of four cardinal domains and three related domains of primary care and user affiliation with the care source $^{15}$.

Starfield et al. ${ }^{15}$ defined four cardinal primary care domains: first-contact access, longitudinality, comprehensiveness, and coordination. The same authors also proposed three related domains: family centeredness, community orientation, and cultural competence.

The PCAT, originally made up of 77 questions (items) about the seven primary care domains, was created based on a health service quality assessment model proposed by Donabedian ${ }^{17}$ which uses a structure, process and outcome framework ${ }^{17}$. Based on a Likert-type response scale, each domain is scored on a scale of one to four. The final score for each domain is represented by the average of the scores assigned to each of the items related to each domain. Some of the domains are made up of subdomains, for example: first-contact access (first contact and use), comprehensiveness (services received and services available) and coordination (information system and flow of service users). The essential primary health score is represented by the sum of the final average score assigned to each of the four cardinal primary care domains and their subdomains and the average extent of affiliation score. The overall primary health score is represented by the sum of the final average score assigned to each of the four cardinal primary care domains and the final average scores assigned to each of the three related domains ${ }^{16}$.

This tool also has a child version (PCAT-CE with 55 items), adult version used only with individuals aged over 18 years (PCAT-AE with 87 items), and provider version (PCAT-PE with 77 items $)^{18}$.

The EUROPEP was developed to provide feedback on practice, performance and organization of care among family health professionals. The EUROPEP has three components: 1) Key indicators (relationship and communication, medical care, information and support, continuity and cooperation, and service organisation);2) indicators of specific areas of satisfaction (consultations, appointments and accessibility, characteristics of doctors, conditions at the health centre, and the services provided); 3) user information (socioeconomic and health data, and post-questionnaire attitudes) ${ }^{19}$.

The PCAT and EUROPEP are used in Brazil along with another tool for assessing PHC called the Program for Improvement in Access and Quality of Primary Care (Programa Nacional de Melhoria do Acesso e da Qualidade da Atenção Básica - PMAQ-AB). Although the search did not return any results mentioning the PMAQ- $A B$, it is important to describe the development of this tool in the Brazilian context.

The aim of the PMAQ is to widen the capacity of health managers, at the federal, state and municipal level, and primary healthcare teams to deliver services that ensure greater access to quality healthcare that meets the concrete needs of the population. The tool also aims to promote greater access to quality PHC that guarantees minimum standards of service at national, regional and local level, and greater transparency and effectiveness in government actions focussed on PHC across the country ${ }^{20}$.

The PMAQ comprises four complementary phases that form a continuous cycle of improvements in the accessibility and quality of primary care (adhesion and contractualisation; develop- 
ment, external assessment, and recontractualisation $)^{20}$.

The analysis of the data collection tools used by the studies selected by our search shows that the most adequate tool for assessing essential aspects of primary health care service provision is the PCAT. This tool measures the presence and extent of the essential characteristics of primary care and at the same time assess indicators which address aspects related to the care process, such as the performance of family health teams. The tool is particularly appropriate to the Brazilian context and the work of family health teams because it enables the researcher to address family centeredness, community orientation, and cultural competence. These additional aspects of primary care are in line with Brazil's National Primary Health Care Policy whose main strategy for expanding and strengthening PHC is family health ${ }^{2}$.

\section{Conclusion}

The search for the "most adequate" tool for assessing PHC reveals that the fundamental aim of developing such instruments is the production of reliable scientific knowledge to support decision making ${ }^{21}$.

The choice of an adequate assessment tool should therefore consider aspects of PHC that need to be revised and improved by health managers and the results of assessments of PHC using these tools should provide concrete information to support the creation of new proposals that contribute to improvements in family health.

The analysis of the five validated tools found by the literature review undertaken by this study shows that the PCAT is the tool that is most aligned with the family health strategy as proposed by Brazil's National Primary Health Care Policy and is therefore the most adequate tool for assessing primary care in this country. 


\section{Collaborations}

LA Fracolli, MFP Gomes and FRZ Nabão carried out the literature review and data analysis, produced the tables, and helped draft the final version of this article. MS Santos, VK Capellini and ACC Almeida were responsible for data interpretation and drafting and revising the final version of this article.

\section{References}

1. Giovanella L. Atenção Primária à Saúde seletiva ou abrangente? Cad Saude Publica. 2008; 24(Supl. 1):2123.

2. Brasil. Ministério da Saúde (MS). Promoção da saúde: carta de Ottawa, declaração de Adelaide, Sundsvall e Santa Fé de Bogotá. Brasília: MS; 1996.

3. Brasil. Ministério da Saúde (MS). Secretaria de Atenção à Saúde. Departamento de Atenção Básica. Política Nacional de Atenção Básica. Brasília: MS; 2012.

4. Ibañez N, Rocha JSY, Castro PC, Ribeiro MCSA, Forster AC, Novaes MHD, Viana ALD. Avaliação do desempenho da atenção básica no Estado de São Paulo. Cien Saude Colet 2006; 11(3):683-703.

5. Lopes ANM, Fracolli LA. Revisão sistemática de literatura e metassíntese qualitativa: considerações sobre sua aplicação na pesquisa em enfermagem. Texto contexto - enferm. 2008; 17(4):771-778.

6. Atallah AN. Revisão sistemática da literatura e metanálise. Diagnóstico e Tratamento 1997; 2(2):12-15.

7. Sandelowski M, Barroso J. Handbook for synthesizing qualitative research. New York: Springer; 2007.

8. Kringos DS, Boerma WG, Spaan E, Pellny M. A snapshot of the organization and provision of primary care in Turkey. BMC Health Services Research 2011; 11:90.

9. Poder TJ, Mautone JÁ, Manz PH, Frye L, Blum NJ. Managing attention-deficit/hyperactivity disorder in primary care: a systematic analysis of roles and challenges. Pediatrics 2008; 121(1):65-72.

10. Tomasi E, Facchini LA, Osorio A, Fassa AG. Aplicativo para sistematizar informações no planejamento de ações de saúde pública. Rev Saude Publica 2003; 37(6):800-806

11. Castro RCL, Knauth DR, Harzheim E, Hauser L, Duncan BB. Avaliação da qualidade da atenção primária pelos profissionais de saúde: comparação entre diferentes tipos de serviços. Cad Saude Publica 2012; 28(9):17721784.

12. Sala A, Luppi CG, Simões O, Marsiglia RG. Integralidade e Atenção Primária à Saúde: avaliação na perspectiva dos usuários de unidades de saúde do município de São Paulo. Saude soc 2011; 20(4):948-960.

13. Silva EM, Assis MMA, Villa TCS, Scatenae LM. Coordenação dos serviços de atenção primária em saúde no controle da tuberculose em um município da Bahia, Brasil. Rev. Baiana de Saúde Pública 2010; 34(2):227239. 
14. Jaturapatporn D, Hathirat S, Manataweewat B, Dellow AC, Leelaharattanarak S, Sirimothya S, Dellow J, Udomsubpayakul U. Reliability and validity of a Thai version of the General Practice Assessment Questionnaire (CPAQ). J Med Assoc Thai 2006; 89(9):1491-1496.

15. Starfield B, Xu J, Shi L. Validating the Adult Primary Care Assessment Tool. The Journal of Family Practice 2001; 50(2):161-175.

16. Harzheim E, Starfield B, Rajmil L, Alvarez-Dardet C, Stein AT. Internal consistency and reliability of Primary Care Assessment Tool (PCATool-Brasil) for child health services. Cad Saude Publica 2006; 22(8):1649-1659.

17. Donabedian, A. The Quality of Care: How Can It Be Assessed? JAMA 1988; 260(12):1743-1748.

18. Brasil. Ministério da Saúde (MS). Secretaria de Atenção em Saúde. Departamento de Atenção Básica. $M a-$ nual do Instrumento de avaliação da atenção primária à saúde: primary care assessment tool pcatool - Brasil. Brasília: MS; 2010.

19. Brandao ALRBS, Giovanella L, Campos CEA. Avaliação da atenção básica pela perspectiva dos usuários: adaptação do instrumento EUROPEP para grandes centros urbanos brasileiros. Cien Saude Colet 2013; 18(1):103114.

20. Brasil. Ministério da Saúde (MS). Secretaria de Atenção à Saúde. Departamento de Atenção Básica. PMAQ: Manual instrutivo para as equipes de Atenção Básica. Brasília: MS; 2013.

21. Novaes HMD. Avaliação de programas, serviços e tecnologias em saúde. Rev Saude Publica 2000; 34(5):547559 .

Article submitted on 05/03/2014

Approved 27/05/2014

Final version submitted on 29/05/2014 